\title{
TINGKAT EFISIENSI PETANI SEBAGAI SALAH SATU INDIKATOR DAMPAK PENGEMBANGAN SISTEM USAHA TANI MINAPADI DI DESA NANGGERANG, BINONG, KABUPATEN SUBANG
}

\author{
Mohammad Noor ${ }^{\star}$
}

\begin{abstract}
ABSTRAK
Survai untuk mengetahui dampak penerapan hasil penelitian dalam pengembangan sistem usaha tani minapadi yang telah dilakukan pada tahun 1993 terhadap tingkat efisiensi petani dan pendapatan di Desa Nanggerang, Kecamatan Binong, Kabupaten Subang, Jawa Barat.

Dari analisis tingkat efisiensi dan pendapatan diketahui bahwa secara keseluruhan tingkat pendapatan tertinggi dicapai oleh petani koperator diikuti oleh petani nonkoperator dan terendah oleh petani biasa. Pendapatan petani koperator pada tahun 1992/1993 secara nominal meningkat sebesar Rp 2,51/jam/tenaga kerja dari pendapatan tahun 1990/1991. Pendapatan petani nonkoperator meningkat sebesar Rp 1,96/jam/tenaga kerja, sedangkan untuk petani biasa peningkatan sangat kecil dibanding petani koperator dan nonkoperator, yaitu sebesar $R p$ 0,44/jam/ tenaga kerja $(61,97 \%)$.
\end{abstract}

\section{ABSTRACT: Efficiency level of farmer as an indicator for the development impacts of rice cum fish farming system in Nanggerang village, Binong, Subang. By: Mohammad Noor.}

An investigation was carried out to study the impacts of application of research result on the development of rice cum fish farming in 1993 in Nanggerang village, Subang, West Java.

The result of analysis showed that, as a whole, the highest productivity was achieved by cooperative farmer followed by non cooperative farmer and the lowest productivity was achieved by ordinary farmers. Net income of the cooperative farmers in 1992/1993 increased by $R_{p} 2.51 /$ hour/man compared to the income in 1990/1991. Net income of non cooperative farmers increased by $R$ p 1.96/hour/man, while the increase of income of ordinary farmer was very small compared to those of cooperative and non cooperative farmers reaching only $R p 0.44 /$ hour $/$ man (61.97\%).

KEYWORDS: Efficiency; farmers; development impacts; potential; rice cum fish farming system.

\section{PENDAHULUAN}

Produksi padi dan pendapatan usaha tani yang berkelanjutan di daerah lahan irigasi dan tadah hujan pada kondisi sistem produksi yang intensif dengan tingkat pemupukan yang tinggi merupakan persoalan yang kritis. Selain itu, pertumbuhan varietas padi juga dibatasi oleh potensi genetiknya. Tambahan lagi, masukan atau pembaharuan dari teknologi produksi padi tanpa mempertimbangkan kecocokan lahan merupakan persoalan baru bagi keberlanjutan produksi padi dan pendapatan usaha tani, pada gilirannya terobosan ini mungkin akan mengakibatkan penurunan efisiensi secara ekonomis.
Menyadari situasi ini pemerintah telah mengubah strategi pembangunan pertanian dari pendekatan satu komoditas menjadi pendekatan diversifikasi atau multi-komoditas pertanian untuk menopang kecukupan dan peningkatan kesejahteraan petani. Hal ini mengingat bahwa Indonesia memiliki lahan irigasi dan tadah hujan yang cukup besar, yaitu masing-masing 4,15 dan 2,17 juta ha. Salah satu usaha diversifikasi adalah usaha tani minapadi yang pengembangannya telah dilakukan oleh Puslitbang Tanaman Pangan bersama Lembaga Penelitian dan instansi terkait lainnya dari tahun 1987 sampai dengan 1989 di Desa Nanggerang, Kecamatan Binong, Kabupaten Subang, Jawa Barat.

) Peneliti pada Balai Penelitian Perikanan Laut, Jakarta 
Berdasarkan hasil penelitian pengembangan ini diketahui bahwa sistem usaha tani minapadi dapat meningkatkan produksi padi dengan kepadatan ikan antara 2.500 sampai 3.500 ekor per ha (Sabri et al. dalam Oka et al., 1992), dan total pendapatan pada sistem usaha tani minapadi ini mencapai 1,5 kali lipat dibanding dengan hanya tanam padi (Oka et al., 1992). Akan tetapi peningkatan produksi belumlah berarti memaksimumkan keuntungan (Smith, 1986) atau dengan kata lain meningkatkan kesejahteraan petani. Banyaknya komponen yang saling terkait dalam suatu sistem produksi, sering menimbulkan kesulitan dalam pengukurannya.

Untuk itu, dilakukan cara pendekatan dengan pengukuran tingkat efisiensi ${ }^{*}{ }^{*}$. Hasil pengukuran efisiensi pada suatu waktu merupakan patokan bagi peningkatan efisiensi di waktu yang lain. Dengan analisis pengukuran tingkat efisiensi, akan dapat diketahui kelemahan-kelemahan yang ada pada suatu sistem usaha tani, di mana kekurangan atau kelemahan ini dapat diperbaiki di masa yang datang.

Penelitian ini bertujuan untuk memperoleh informasi dampak pengembangan sistem usaha tani minapadi terhadap tingkat efisiensi petani di Desa Nanggerang, Kecamatan Binong, Kabupaten Subang, Jawa Barat.

\section{METODE PENELITIAN}

Pendekatan dan metode yang digunakan adalah zero-one relationship approach, yaitu membagi petani yang dipilih menjadi dua kelompok, yaitu kelompok yang dibina dan dikembangkan (koperator) dan kelompok yang tidak dibina tetapi dipantau kegiatan sistem usaha taninya (nonkoperator), ditambah dengan kelompok tani biasa (petani yang tidak termasuk petani koperator maupun nonkoperator) yang tidak menjalankan sistem usaha tani mina padi. Pengambilan sampel dilakukan dengan acak sederhana di mana jumlah petani responden yang terpilih sebanyak 60 orang petani, terdiri atas 22 orang petani koperator, 22 orang petani nonkoperator dan 16 orang petani biasa.

\footnotetext{
*) Pengertian "Efisiensi" adalah menghasilkan produk yang relatif banyak dalam waktu singkat dan tenaga yang minimal.
}

Data primer diperoleh dengan wawancara yang didasarkan pada kuisioner terpola maupun semi struktural tanpa kuisioner yang berpedoman pada topik dan subtopik yang telah disusun terlebih dahulu dengan berbagai pihak terkait.

Analisis yang digunakan adalah pengukuran tingkat efisiensi hasil produksi padi, hasil produksi ikan, pendapatan kotor dan pendapatan bersih per hektar. Juga dilakukan uji banding dengan tingkat efisiensi yang diperoleh pada tahun-tahun sebelumnya guna memperoleh gambaran yang lebih jelas mengenai dampak pengembangan sistem usaha tani minapadi.

Penelitian ini dilakukan pada bulan Mei 1993 di Desa Nanggerang, Kecamatan Binong, Kabupaten Subang, Jawa Barat.

\section{HASIL DAN PEMBAHASAN}

Analisis tingkat efisiensi berdasarkan indikator produksi padi, produksi ikan, pendapatan kotor dan pendapatan bersih sistem usaha tani minapadi disajikan pada Tabel 1.

Berdasarkan Tabel 1 diketahui bahwa tingkat efisiensi tertinggi untuk produksi padi diperoleh oleh petani koperator ( $R p$ 2,65/jam/tenaga kerja), sedangkan yang terendah diperoleh oleh petani nonkoperator ( $\operatorname{Rp~2,29~/~jam~/~tenaga~kerja).~}$ Selanjutnya untuk tingkat efisiensi produksi ikan tertinggi dicapai oleh petani koperator $(\operatorname{Rp} 2,87$ I jam/tenaga kerja). Demikian juga dengan pendapatan kotor dan bersih diperoleh oleh petani koperator, yaitu masing-masing sebesar $\mathrm{Rp} 5,52 /$ jam/tenaga kerja dan Rp 3,57/jam/tenaga kerja.

Efisiensi produksi padi petani koperator lebih tinggi dibandingkan dengan petani nonkoperator. Hal ini disebabkan karena petani koperator melakukan usaha penanaman ikan secara intensif, sehingga frekuensi turun ke sawah lebih tinggi. Akibatnya pengawasan terhadap tanaman padipun lebih intensif sehingga efisiensinya lebih tinggi.

Jelas pula terlihat bahwa tingkat efisiensi produksi ikan petani koperator lebih tinggi dari pada petani nonkoperator. Secara keseluruhan tingkat efisiensi tertinggi dicapai oleh petani koperator.

Tingginya tingkat efisiensi petani koperator secara umum dikarenakan petani koperator langsung memperoleh informasi dan bimbingan 
teknologi sistem usaha tani minapadi dari para peneliti maupun pihak terkait lainnya. Sedangkan untuk petani nonkoperator walaupun kegiatan sistem usaha tani minapadi mereka tetap dipantau, akan tetapi akses ke sumber informasi teknologi tidak langsung mereka peroleh. Demikian juga halnya dengan petani biasa mereka sama sekali tidak menerima informasi teknologi. Ravianto (1986) mengemukakan bahwa tingkat efisiensi suatu sistem produksi juga sangat dipengaruhi oleh faktor-faktor yang tidak dapat diukur (invisible input), yaitu berupa kekuatan motivasi (motivation power), pengetahuan (know- ledge), teknologi serta organisasi. Semua itu kurang dimiliki oleh petani nonkoperator maupun petani biasa.

Selanjutnya untuk mendapatkan gambaran sampai sejauh mana tingkat efisiensi yang telah dicapai oleh petani baik koperator, nonkoperator maupun petani biasa, dengan telah dilaksanakannya penelitian pengembangan sistem usaha tani minapadi ini, dilakukan uji banding tingkat efisiensi yang telah dicapai pada tahun-tahun sebelumnya, yang hasilnya disajikan pada Tabel 2 dan Tabel 3.

Tabel 1. Analisis tingkat efisiensi petani koperator, petani nonkoperator dan petani biasa di Desa Nanggerang (musim tanam 1992/1993, Rp/orang/jam).

Table 1. Analysis of efficiency levels of cooperative, non-cooperative and ordinary farmers in Nanggerang village (1992/1993 crop season, $R p /$ man/hour).

\begin{tabular}{lccc}
\hline \multicolumn{1}{c}{$\begin{array}{c}\text { Produktivitas } \\
\text { Productivity }\end{array}$} & $\begin{array}{c}\text { Petani koperator } \\
\text { Cooperative farmer }\end{array}$ & $\begin{array}{c}\text { Petani nonkoperator } \\
\text { Non-cooperative farmer }\end{array}$ & $\begin{array}{c}\text { Petani biasa } \\
\text { Ordinary farmer }\end{array}$ \\
\hline $\begin{array}{l}\text { Produksi padi } \\
\text { Rice production output } \\
\begin{array}{l}\text { Produksi ikan } \\
\text { Fish production output }\end{array}\end{array}$ & 2.65 & 2.29 & 2.45 \\
$\begin{array}{l}\text { Pendapatan kotor } \\
\text { Gross Revenue }\end{array}$ & 2.87 & 1.63 & 0 \\
$\begin{array}{l}\text { Pendapatan bersih } \\
\text { Net Income }\end{array}$ & 5.52 & 3.92 & 2.45 \\
\hline
\end{tabular}

Tabel 2. Analisis tingkat efisiensi petani koperator, petani nonkoperator dan petani biasa di Desa Nanggerang (musim tanam 1989/1990, Rp/orang/jam).

Table 2. Analysis of efficiency levels of cooperative, non-cooperative and ordinary farmers in Nanggerang vilage (1989/1990 crop season, $\mathrm{Rp} / \mathrm{man} /$ hour).

\begin{tabular}{lccc}
\hline \multicolumn{1}{c}{$\begin{array}{c}\text { Produktivitas } \\
\text { Productivity }\end{array}$} & $\begin{array}{c}\text { Petani koperator } \\
\text { Cooperative farmer }\end{array}$ & $\begin{array}{c}\text { Petani nonkoperator } \\
\text { Non-cooperative farmer }\end{array}$ & $\begin{array}{c}\text { Petani biasa } \\
\text { Ordinary farmer }\end{array}$ \\
\hline $\begin{array}{l}\text { Produksi padi } \\
\text { Rice production output }\end{array}$ & 3.00 & 2.85 & 2.54 \\
$\begin{array}{l}\text { Produksi ikan } \\
\text { Fish production output }\end{array}$ & 0.35 & 0.26 & 0 \\
$\begin{array}{l}\text { Pendapatan kotor } \\
\text { Gross Revenue }\end{array}$ & 3.36 & 3.11 & 2.25 \\
$\begin{array}{l}\text { Pendapatan bersih } \\
\text { Net Income }\end{array}$ & 1.99 & 1.84 & 1.20 \\
\hline
\end{tabular}

Sumber (Source): Oka et al., 1992 
Noor, $M$.

Tabel 3. Analisis tingkat efisiensi petani koperator, petani nonkoperator dan petani biasa di Desa Nanggerang (musim tanam 1990/1991, Rp/orang/jam).

Table 3. Analysis of efficiency levels of cooperative, non-cooperative and ordinary farmers in Nanggerang vilage (1990/1991 crop season, Rp/man/hour).

\begin{tabular}{lccc}
\hline \multicolumn{1}{c}{$\begin{array}{c}\text { Produktivitas } \\
\text { Productivity }\end{array}$} & $\begin{array}{c}\text { Petani koperator } \\
\text { Cooperative farmer }\end{array}$ & $\begin{array}{c}\text { Petani nonkoperator } \\
\text { Non-cooperative farmer }\end{array}$ & $\begin{array}{c}\text { Petani biasa } \\
\text { Ordinary farmer }\end{array}$ \\
\hline $\begin{array}{l}\text { Produksi padi } \\
\text { Rice production output } \\
\text { Produksi ikan }\end{array}$ & 1.99 & 2.27 & 2.13 \\
$\begin{array}{l}\text { Fish production output } \\
\text { Pendapatan kotor }\end{array}$ & 0.56 & 0.26 & 0 \\
$\begin{array}{l}\text { Gross Revenue } \\
\begin{array}{l}\text { Pendapatan bersih } \\
\text { Net Income }\end{array}\end{array}$ & 2.55 & 2.53 & 2.13 \\
\hline
\end{tabular}

Sumber (Source): Oka et al., 1992

Berdasarkan Tabel 2 dan Tabel 3 diketahui bahwa tingkat efisiensi tertinggi secara umum diperoleh oleh petani koperator dan terendah oleh petani biasa. Perbedaan tingkat efisiensi produksi ikan tahun 1992/1993 dibanding tahun-tahun sebelumnya yang dicapai oleh petani koperator disebabkan karena tingkat intensitas penanaman ikan yang jauh lebih tinggi pada tahun 1992/ 1993. Hal ini juga jelas terlihat dari hasil yang dicapai tahun 1992/1993 antara petani koperator dengan nonkoperator, seperti yang telah diuraikan di atas.
Jumlah induk yang ada, yaitu 183 ekor betina (718 kg) dengan bobot rata-rata 3,92 kg/ekor, dan induk jantan sebanyak 698 ekor $(630 \mathrm{~kg})$ dengan bobot rata-rata 0,90 kg/ekor. Perbandingan antara induk jantan dan betina adalah 1:4.

Produksi benih untuk bulan Maret dan April 1993 masing-masing 2.834.000 dan 3.927.000 ekor dengan ukuran $1-3 \mathrm{~cm}$.

Analisis pendapatan petani koperator dan nonkoperator dapat dilihat pada Tabel 4 .

Tabel 4. Analisis pendapatan petani koperator dan nonkoperator MT 1992/1993 (Rp/ha/musim tanam). Table 4. Income analysis of cooperator and non-cooperator farmers in 1992/1993 (Rp/ha/crop season).

\begin{tabular}{lcc}
\hline \multicolumn{1}{c}{$\begin{array}{c}\text { Komponen } \\
\text { Component }\end{array}$} & $\begin{array}{c}\text { Petani Koperator } \\
\text { Cooperative farmer }\end{array}$ & $\begin{array}{c}\text { Petani nonkoperator } \\
\text { Non-cooperator farmer }\end{array}$ \\
\hline Penerimaan padi (Rice income) & 2.634 .722 & 2.653 .505 \\
Penerimaan ikan (Fish income) & 2.884 .612 & 1.481 .518 \\
Pendapatan kotor (Gross revenues) & 5.519 .334 & 4.135 .023 \\
Biaya sarana produksi (Cost of production & 913.492 & 517.482 \\
facilities) & & 907.425 \\
Biaya tenaga kerja (Cost of labor) & 1.003 .585 & 1.424 .907 \\
Total biaya (Total costs) & 1.935 .077 & 2.710 .116 \\
Penerimaan bersih (Net income) & 3.584 .257 & \\
\hline
\end{tabular}


Hasil analisis efisiensi menunjukkan adanya peningkatan efisiensi dari tahun ketahun. Peningkatan efisiensi pendapatan bersih petani koperator tahun 1992/1993 dibanding tahun sebelumnya 1989/1990 adalah sebesar Rp 1,58/ jam/tenaga kerja $(79,40 \%)$. Untuk tahun $1992 /$ 1993 dibanding tahun 1990/1991 meningkat sebesar Rp 2,51/jam/tenaga kerja (236,79\%). Sedangkan untuk petani nonkoperator peningkatan efisiensi pendapatan bersih tahun 1992/1993 dibanding tahun 1990/1991 adalah sebesar Rp1,69/jam/tenaga kerja (190,29\%). Selanjutnya pada petani biasa walaupun terjadi peningkatan efisiensi pendapatan bersih tahun 1992/1993 dibanding tahun 1990/1991, namun peningkatannya jauh lebih kecil dibandingkan dengan petani koperator dan nonkoperator, yaitu sebesar Rp0,44/jam/tenaga kerja (61,97\%).

Lonjakan tingkat efisiensi dan pendapatan bersih yang besar pada petani koperator ini pada tahun 1992/1993 dibanding tahun-tahun sebelumnya adalah disebabkan terjadinya pergeseran pola usaha produksi, sedang pola tanam tetap yaitu minapadi - penyelang (ikan) - minapadi palawija - ikan (Koeshendrajana dan Sadili, 1989). Perubahan ini terjadi akibat perubahan permintaan pasar. Pada pola usaha produksi yang lama ukuran ikan yang ditanam adalah benih berukuran $3-5 \mathrm{~cm}$ (ngaramo/fingerling) dengan padat penebaran antara 2.500-3.500/ha. Lama pemeliharaan antara 2-3 bulan dan siap dipanen sebagai ikan konsumsi atau benih untuk dibesarkan pada sistem budidaya ikan dalam keramba jaring apung di Waduk Cirata, Jatiluhur dan Saguling serta untuk benih sistem budidaya ikan dalam kolam air deras (Oka et al., 1992).

Pada awal tahun 1992 atau sekitar akhir tahun 1991 karena sulitnya memperoleh benih ukuran 100 g/ekor untuk dibesarkan di keramba jaring apung, maka petani keramba jaring apung di Waduk Cirata, Saguling dan Jatiluhur sesuai dengan hasil penelitian yang telah dilakukan oleh Puslitbang Perikanan dan hasil penelitian Schmittou (1991) melakukan perubahan benih yang dibesarkan di dalam keramba jaring apung dari ukuran 100 g/ekor menjadi ukuran 40-60 ekor/kg atau sekitar 20-30 g/ekor. Perubahan permintaan pasar ini dengan cepat ditanggapi oleh petani koperator sehingga terjadi perubahan pola usaha produksi sistem usaha tani minapadi dan ternyata perubahan ini memberikan keuntungan yang besar bagi petani koperator.
Pola usaha produksi yang saat ini diterapkan oleh petani koperator adalah menanam ikan mulai dari ukuran benih kebul yang dalam satu liter berisi 5.000-6.000 ekor benih, masa pemeliharaan 20-25 hari dan menghasilkan benih fingerling yang siap untuk dipasarkan sesuai dengan permintaan pasar. Dengan singkatnya masa pemeliharaan, maka dalam satu musim tanam padi baik itu musim hujan (musim rendeng) atau musim kemarau (musim gadu) dapat diproduksi benih ukuran fingerling sebanyak 2 (dua) kali. Pada musim penyelang dapat diproduksi benih fingerling 1 (satu) kali. Sedangkan pada musim palawija ikan petani koperator dapat menanam ikan untuk menghasilkan fingerling sebanyak 2 sampai 5 kali. Petani nonkoperator juga telah menanggapi perubahan permintaan pasar ini tetapi intensitas penanaman yang mereka lakukan lebih rendah dari pada petani koperator, sehingga tingkat efisiensi pendapatan bersih yang mereka terimapun lebih rendah dibanding petani koperator.

Selain itu juga jelas terlihat adanya peningkatan efisiensi dari tahun ke tahun pada petani koperator dan nonkoperator. Ini berarti telah terjadi perubahan sikap mental pada kedua kelompok tani ini. Efisiensi pada dasarnya adalah suatu sikap mental yang selalu mempunyai pandangan bahwa mutu kehidupan hari ini harus lebih baik dari hari kemarin dan hari esok harus lebih baik dari hari ini (Dewan Produktivitas Nasional R.I. tahun 1983 dalam Ravianto, 1986). Sedang Shen (1986) mengemukakan bahwa efisiensi adalah merupakan tingkat efisiensi dari penggunaan sumber daya untuk menghasilkan keluaran.

Seperti telah diuraikan di atas, tingkat efisiensi suatu sistem produksi juga sangat dipengaruhi oleh faktor-faktor yang tidak dapat diukur, yaitu berupa kekuatan motivasi, pengetahuan, teknologi dan organisasi. Hal ini jugalah yang telah menyebabkan perbedaan tingkat efisiensi petani koperator, nonkoperator dan petani biasa. Walaupun petani nonkoperator juga memiliki kekuatan motivasi dengan memperoleh pengetahuan dan teknologi secara tidak langsung akan tetapi mereka tidak memiliki organisasi.

Lain halnya dengan kelompok petani koperator yang memiliki keempat faktor yang tidak dapat diukur. Nama organisasi mereka adalah Kelompok Mina Padi Asem, dengan struktur 
Noor, $M$.

organisasi yang sudah baik seperti yang disajikan pada Gambar 1.

Hasil penelitian menunjukkan bahwa organisasi Kelompok Tani Mina Padi Asem ini telah menerapkan konsep manajemen modern atau MBO (Management by Objective). Walaupun mungkin secara harfiah mereka tidak mengerti mengenai $\mathrm{MBO}$ ini, akan tetapi pada hakekatnya dan dalam prakteknya prinsip yang mereka terapkan dalam organisasinya adalah konsep MBO, yaitu suatu sistem yang dinamis yang berusaha untuk mengintegrasikan kebutuhan organisasi (kelompok) untuk memperjelas dan mencapai tujuan pertumbuhan organisasi dengan kebutuhan para manajer (dalam hal ini juga sebagai anggota organisasi) untuk memberikan sumbangan yang nyata sambil mengembangkan diri (Siagian, 1983).

Prinsip ini jelas terlihat dari adanya pertemuan-pertemuan para anggota kelompok dengan pengurus yang dilakukan 1 minggu 2 kali untuk membahas masalah dan persoalan yang dihadapi anggota maupun organisasi secara keseluruhan untuk mencari alternatif pemecahannya.

Adanya organisasi yang baik ini jugalah yang telah menyebabkan mengapa petani koperator dapat melakukan penanaman ikan dengan intensitas yang tinggi dibanding dengan petani nonkoperator, sehingga tingkat efisiensi yang mereka capai jauh lebih tinggi dibandingkan petani nonkoperator. Kebutuhan benih untuk petani koperator dipenuhi oleh organisasi, sedangkan petani nonkoperator harus mencari benih sendiri dari pembenih lain di luar kelompok.

Di samping itu, organisasi kelompok tani koperator juga telah menciptakan suatu mekanisme pemasaran ikan bagi para anggotanya untuk menjamin kestabilan harga guna peningkatan pendapatan dan kesejahteraan para anggota, yang mekanisme pemasaran hasil ikannya dapat dilihat pada Gambar 2.

Nyatalah bahwa kelompok tani koperator telah melakukan strategi pemasaran yang baik, guna menjamin kepastian dan kestabilan harga dengan menciptakan mekanisme pemasaran yang baik, sehingga tujuan organisasi untuk meningkatkan pendapatan dan kesejahteraan anggotanya dapat tercapai.

Adanya jaminan kepastian harga produksi dan jaminan input produksi pada petani koperator melalui organisasi yang mereka miliki merupakan driving spirit yang memotivasi mereka untuk lebih meningkatkan efisiensi kerja mereka, sehingga tingkat efisiensi yang mereka capai jauh lebih tinggi dibanding petani nonkoperator maupun petani biasa. Keynes dalam Ravianto (1986) mengemukakan bahwa kemakmuran ekonomi banyak bergantung kepada motivasi, sedang pertumbuhan ekonomi merupakan hasil langsung dari tenaga kerja (Lewis dalam Ravianto, 1986).

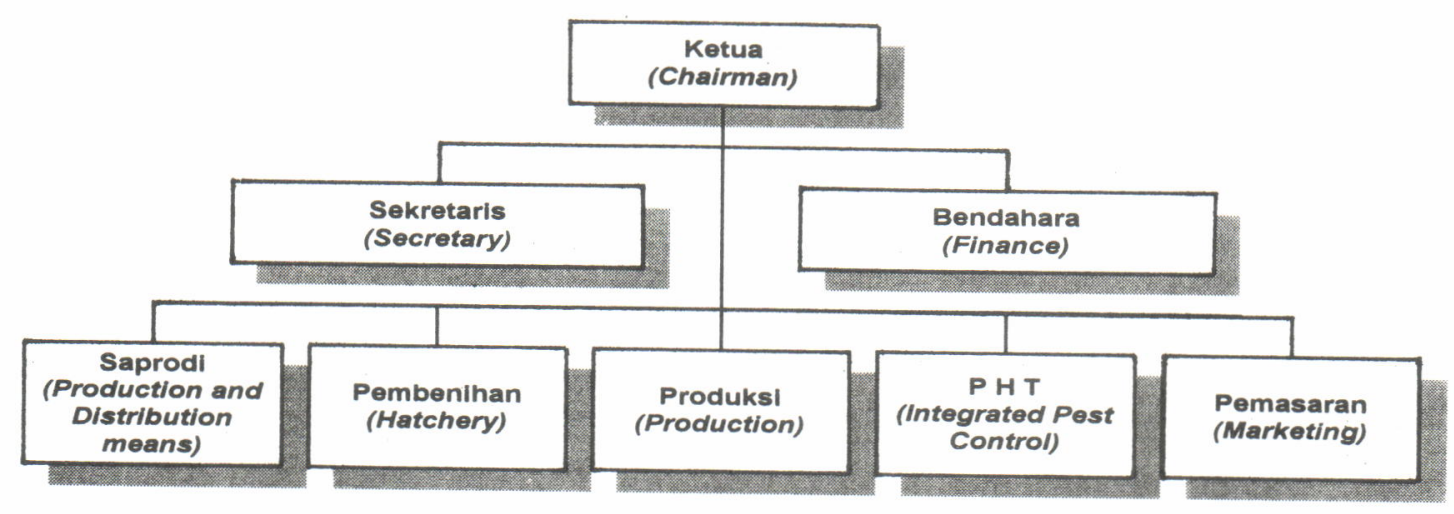

Gambar 1. Diagram organisasi kelompok Mina Padi Asem

Figure 1. Organization diagram of "Mina Padi Asem" group 


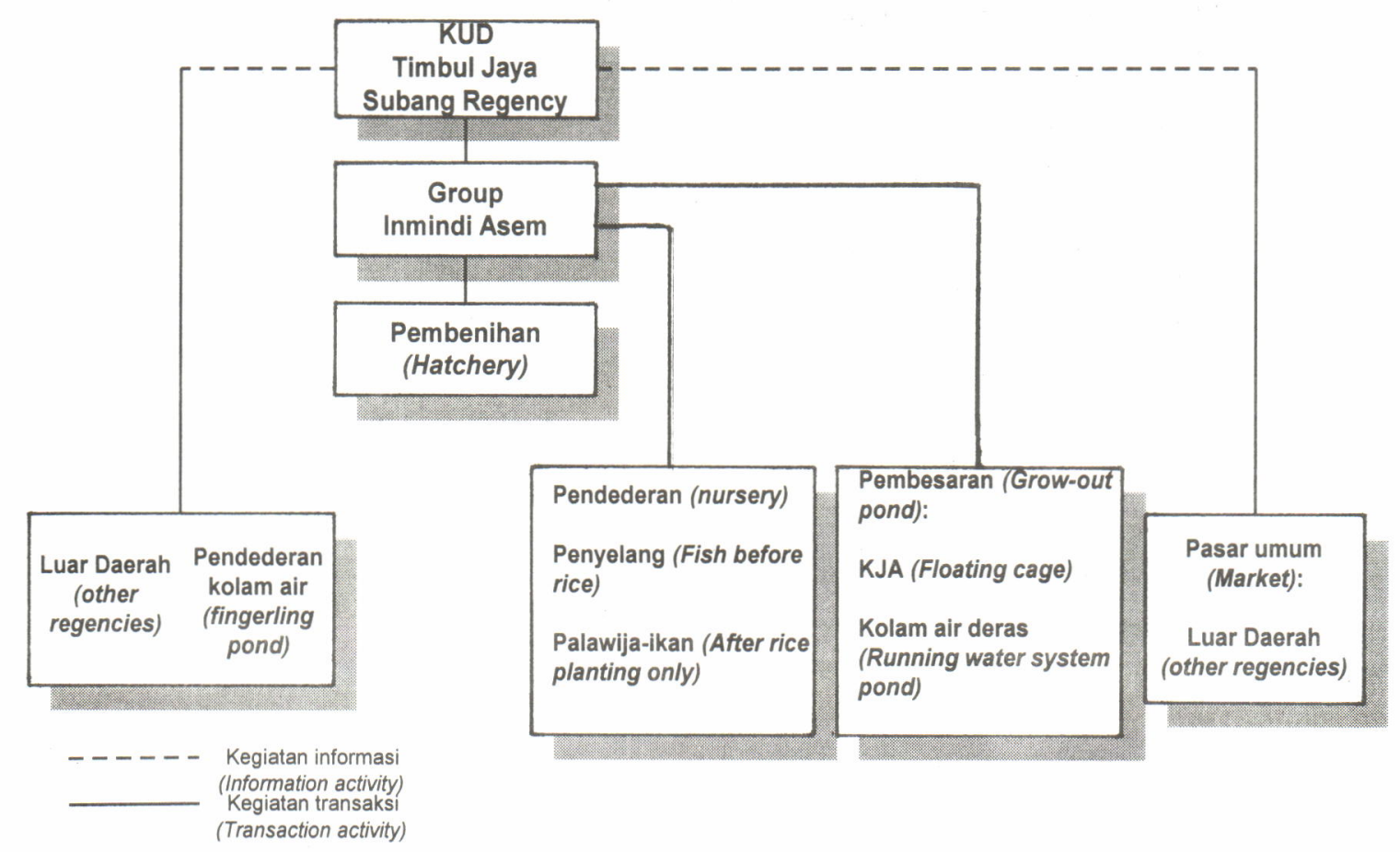

Gambar 2. Mekanisme pemasaran ikan kelompok Tani Asem KUD Timbul Jaya. Figure 2. Fish marketing mechanism of "Tani Asem KUD Timbul Jaya" Group.

Dari uraian-uraian di atas dapat disimpulkan bahwa tingginya tingkat efisiensi pada petani koperator disebabkan keempat faktor penentu yang tidak dapat diukur, yaitu kekuatan motivasi, pengetahuan, teknologi dan organisasi yang telah dimiliki oleh mereka.

\section{KESIMPULAN}

1. Adopsi teknologi sistem usaha tani minapadi di Desa Nanggerang, Binong, Subang, telah berjalan dengan baik dan memberikan dampak yang positif terhadap peningkatan pendapatan dan kesejahteraan petani pada umumnya dan petani koperator pada khususnya.

2. Terjadi peningkatan "efisiensi" dan penerimaan bersih petani koperator sebesar $R p$ $2,51 / j a m /$ tenaga kerja $(236,79 \%)$ pada tahun 1992/1993 dibanding tahun sebelumnya 1990/ 1991. Sedangkan untuk petani nonkoperator pada tahun yang sama adalah sebesar $\mathrm{Rp}$ 1,96/jam/tenaga kerja (190,29\%). Selanjutnya untuk petani biasa peningkatan efisiensi penerimaan bersih tahun 1992/1993 dibanding tahun 1990/1991 adalah sebesar Rp 0,44/jam/ tenaga kerja (61,97\%).

3. Adanya organisasi serta mekanisme pemasaran hasil produksi ikan yang baik pada petani koperator dapat memberi motivasi kepada mereka untuk meningkatkan efisiensinya.

\section{DAFTAR PUSTAKA}

Koeshendrajana dan D. Sadili. 1991. Studi ekonomi budidaya ikan mas dan budidaya ikan nila merah dalam keramba jaring apung di Waduk Cirata, Jawa Barat. Bull. Pen. Perik. Darat. Bogor. 2: 112-117.

Oka, M.A.; D.K.S. Swastika dan W. Sudana. 1992. Impact assessment of rice fish farming system in Indonesia. CRIFC. AARD. Bogor, $42 \mathrm{p}$.

Ravianto, J. 1986. Produktivitas dan pengukuran: Kumpulan Kertas Kerja: Bagaimana mengukur produktivitas. Seri Produktivitas VIII. Lembaga sarana informasi usaha dan efisiensi. Jakarta. 196 hal. 
Siagian, P.S. 1983. Managemen modern. Bunga Rampai, Gunung Agung. Jakarta, 160 hal.

Schmittou, H. R. 1991. Cage culture: A Method of fish production in Indonesia. FRDP - CRIFI. Jakarta, $114 \mathrm{p}$.

Shen, C.G. 1986. Pendekatan pengukuran produktivitas: Dalam Efisiensi dan pengukuran: Kumpulan
Kertas Kerja : Bagaimana mengukur produktivitas. Seri Produktivitas VIII. Sarana informasi usaha dan efisiensi. hal 26-42.

Smith, R.I. 1986. Ekonomi mikro dari sistem produksi budidaya perairan yang sekarang: Konsepsi dasar dan Defenisis. Dalam Penelitian Ekonomi Budidaya Perairan di Asia. Koordinator William, L. Collier. Yayasan Obor Indonesia. Jakarta. hal 9. 35 . 